\title{
Patterns of Communication Between Gay and Lesbian Patients and Their Health Care Providers
}

\author{
Robert L. Klitzman, MD \\ Columbia University \\ Jason D. Greenberg, PhD \\ Jacobi Medical Center
}

\begin{abstract}
Objectives: To determine whether gay men and lesbians disclose their sexual orientation, and other sensitive behaviors to their primary care physicians; whether they have a chance of finding a gay friendly physician; and what factors are involved. Methods: A self-report questionnaire was administered to 66 gay men and 28 lesbians at a gay and lesbian community center. Results: Less than half of participants felt their health insurance plan gave them a choice of finding a lesbian, gay, or bisexual (LGB) doctor. Those who did were more likely to be older, male, and to feel more comfortable discussing sex. Men were
\end{abstract}

Robert L. Klitzman is Assistant Professor of Clinical Psychiatry at Columbia University. Jason D. Greenberg is a staff psychologist at Jacobi Medical Center, Bronx, NY.

This work was supported by grants from the Russell Sage Foundation, and the NIMH (K08-MH01420-01).

The authors would like to thank Jesse Green and Sabia Ali for their assistance with this research.

Correspondence may be addressed: Robert L. Klitzman, HIV Center for Clinical and Behavioral Studies, New York State Psychiatric Institute and Columbia University Department of Psychiatry, 1051 Riverside Drive, Unit 15, New York, NY 10032 (E-mail: RLK2@columbia.edu).

Journal of Homosexuality, Vol. 42(4) 2002

www.haworthpressinc.com/store/product.asp?sku=J082

(C) 2002 by The Haworth Press, Inc. All rights reserved. 
more likely to disclose their sexual orientation to their health care provider (HCP), to feel very comfortable discussing sex, to have a male doctor, to have a choice of finding a LGB provider through their insurance plan, and to think their provider is LGB. Those who disclosed their sexual orientation to their providers were more likely to be white males with male doctors, who felt their doctor was very gay friendly, and to have also discussed substance use, sexual behavior, and HIV with their HCP, and to feel comfortable discussing sex. Discussion: Lesbians in particular have difficulty disclosing their sexual orientation to providers, possibly due to continuing stigma, and to have less of a choice of finding a gay or lesbian provider. The data suggest that health insurance plans should provide patients with the opportunity to find gay friendly physicians, as it may facilitate communication about substance use, high risk sexual behavior and other health topics. [Article copies available for a fee from The Haworth Document Delivery Service: 1-800-HAWORTH. E-mail address: <getinfo@ haworthpressinc.com> Website: <http://www.HaworthPress.com> (c) 2002 by The Haworth Press, Inc. All rights reserved.]

KEYWORDS. Physicians, lesbians, gay men, sexual behavior, health insurance, doctor-patient relationship, homosexuality

\section{INTRODUCTION}

Primary physicians have been found to be uncomfortable with sexuality and with homosexuality, and as a result, gay men and lesbians may not always disclose their sexual orientation or details of their sexual behavior to their physicians. Among physicians, only $32.7 \%$ felt comfortable with gay men, $40.8 \%$ felt gay men should not work in schools, and $11.4 \%$ felt homosexuality was an illness (Bhugra, 1989). Moreover, with managed care, many gays and lesbians may also be concerned about lack of confidentiality and of employers and others seeing medical records which may discourage disclosure of sexual orientation.

Several studies have suggested that gays and lesbians do not always disclose their sexual orientation to health care providers (HCPs). A British study found that $44 \%$ of gay male patients did not disclose their homosexuality to their primary physicians (Fitzpatrick, Dawson, Boulton, McLean, Hart, \& Brookes, 1994). Of HIV-positive gay men, $37 \%$ disclosed their sexual orientation to their general practitioner only after HIV diagnosis (Fitzpatrick et al., 1994). Of African-American les- 
bians and bisexual women, $45 \%$ said their sexual orientation was unknown to their physician (Cochran \& Mays, 1988).

Among gays and lesbians, degree of openness about sexuality and sexual orientation in general has been described as relating to several factors, including self-acceptance (Cass, 1979; Coleman, 1982) and concern with others' reaction. Most gays and lesbians perceived self-disclosure as a risk (Franke \& Leary, 1991). Lesbians rely more on perceptions that the recipient will respond favorably, and on a high prior trust level, and prefer more than gay men to disclose to other gays and lesbians rather than to heterosexuals (Wells \& Kline, 1986).

Qualitative research has suggested that lesbians often hide their sexual orientation in order to receive health care, or choose not to receive care at all (Jay \& Young, 1979). Among lesbians, 40\% fear receiving inferior health care from providers if they disclose their HIV status, $84 \%$ find providers "nonempathetic," and 96\% imagine their care would be less if they disclosed (Stevens \& Hall, 1988). Even when asked by their physicians, patients do not always accurately disclose their sexual orientation (Franke \& Leary, 1991). However, these studies were conducted almost ten years ago, and changes may have occurred since then in the acceptance of homosexuality. Moreover, several other factors such as ethnicity, type of health care or health insurance, and disclosure of other potentially sensitive areas may be related to the disclosure of sexual orientation.

These issues are important as primary physicians can serve potentially vital roles in prevention of HIV and other STDs (Klitzman, 1997), and may thus be a significant underutilized resource in HIV-prevention. Primary physicians can improve short-term health-related risk behavior in other areas, such as smoking cessation (AMA Council on Scientific Affairs, 1996; Logsdon, Lazaro, \& Meier, 1989). Primary physician encounters, given their intimacy and the possibility of trust established over time, are ideally suited for discussions of sexual behavior, prevention of HIV and of relapses of unsafe sexual behaviors.

Several studies have shown that physicians usually do not ask about patient's HIV risks and sexual behavior. Less than one-sixth of patients talk to physicians about alcohol or substance use or sexually transmitted diseases (Schauffler, Rodriguez, \& Milstein, 1996). Among patients surveyed, only $16 \%$ had discussed AIDS with their physician (Gerbert, Maguire, Bleeker, Coates, \& McPhee, 1991), and of these patients, 64\% had initiated the discussion.

Gay men and lesbians may feel uncomfortable disclosing to physicians other sensitive but important related information. Gays and lesbi- 
ans also have higher rates of substance abuse than the general population (Cabaj, 1992), yet may not disclose use of drugs, including those used in sexual encounters. Gay and lesbian patients who feel they cannot disclose important aspects of their lives to their physicians may trust physicians less, and thus not disclose other potentially sensitive issues such as non-adherence to treatments.

It may be difficult for gay and lesbian patients to raise these issues if their physicians do not, as the practitioner-patient relationship can be "asymmetrical" and "hierarchical" (Fox, 1989; Parsons, 1975), with physicians predominantly asking questions, while patients answer them (West, 1984). These issues are becoming more critical as a result of recent changes in health care, notably the rise of managed care, giving physicians less time to spend with patients.

The present exploratory study examines several questions: what factors are related to whether gay men or lesbians disclose to their providers? What role do factors such as gender, ethnicity and the type of health insurance plan have in these issues of communication with health care providers? Are those who disclose their sexual orientation more likely to disclose other behaviors? Do gays and lesbians feel they have a choice of finding a gay-friendly provider? We hypothesized that those who had disclosed their sexual orientation to their providers would be more likely to disclose other sensitive information, such as mental health and high risk behaviors.

\section{METHODS}

A one page questionnaire was developed and administered one evening at a gay and lesbian community center in New York City. The questionnaire asked basic socio-demographic information, as well as whether the participant had a health care provider (HCP); how often the participant saw the HCP in the last three years; what the HCP's gender is; how gay-friendly the participant felt the HCP was; whether HCP is gay/lesbian or bisexual; whether the participant has ever discussed personal mental health issues, substance use, sex or HIV with the HCP, feels very comfortable discussing sex, is sexually active, has unprotected sex, has ever talked to the HCP about having unprotected sex, takes medications, has missed doses or informs the HCP when missing doses; whether or not the participant has had an STD, knows his or her HIV status, and if so what it is; whether or not he or she has disclosed his

or her HIV status to the provider, has insurance, and if so what type; and 
whether or not the insurance plan gives a choice of finding a LGB provider. The questionnaire is available from the authors.

Ninety-eight questionnaires were distributed and completed. Of these, ninety-four self-identified as gay/lesbian/bisexual, and 4 self-identified as heterosexual and were excluded from the remainder of the analyses. One self-identified as "other."

Analyses were completed using Chi-square statistics and ANOVAs where appropriate. We assessed differences in responses associated with gender. We then examined two dependent variables: disclosing one's sexual orientation to one's HCP and having a choice through one's health plan of finding a gay, lesbian, or bisexual doctor.

\section{RESULTS}

The sample was $70.2 \%$ (66/94) male, and $28.9 \%$ (28/94) female. As shown on Table 1, most of the respondents reported having a primary health care provider. Men were younger, more likely to have a male doctor, to have disclosed their sexual orientation to their HCP, to be very comfortable discussing sex, to think their HCP is gay or bisexual, to think their insurance company gives them a choice of having a gay or lesbian health care provider, to have been HIV tested, to be HIV positive, and to have disclosed their seropositivity, and there were trends for them to have a very gay friendly HCP, to have had an STD, and to be white.

Those who disclosed their sexual orientation (see Table 2) were more likely to be male, white, to have male doctors, to have Medicaid or an $\mathrm{HMO}$ rather than fee-for-service insurance, to have a gay friendly HCP, to think their HCP is gay or bisexual, to discuss substance abuse, and HIV, to feel very comfortable discussing sex, to know their HIV status, and to disclose their HIV status to their HCP; and there were trends with believing their HCP was gay or bisexual, and to have told their HCP about engaging in unprotected sex.

Those who said their health insurance plans gave them a choice of having a LGB doctor (see Table 3 ) were more likely to be older, male, to feel very comfortable discussing sex, and not to have missed doses of medication; and there was a trend with having a male doctor.

\section{DISCUSSION}

The data clearly suggest difficulties faced by lesbians, in comparison with gay men in communication with health care providers. Lesbians 
TABLE 1. Relationships Between Communication and Gender

\begin{tabular}{|c|c|c|c|}
\hline & Male & Female & P-Value \\
\hline Age (ANOVA) & $M=40.69$ & $M=35.11$ & .05 \\
\hline $\begin{array}{l}\text { Sexual Orientation } \\
\text { Gay/Lesbian } \\
\text { Bisexual } \\
\end{array}$ & $\begin{array}{l}87.9 \%(58 / 66) \\
12.1 \%(8 / 66) \\
\end{array}$ & $\begin{array}{l}85.2 \%(23 / 27) \\
14.8 \%(4 / 27) \\
\end{array}$ & n.s. \\
\hline $\begin{array}{l}\text { Race } \\
\text { White } \\
\text { Black } \\
\text { Latino } \\
\end{array}$ & $\begin{array}{c}76.2 \%(45 / 59) \\
8.5 \%(5 / 59) \\
16.3 \%(9 / 59) \\
\end{array}$ & $\begin{array}{l}48.0 \%(12 / 25) \\
24.0 \%(6 / 25) \\
28.0 \%(7 / 25)\end{array}$ & .07 \\
\hline Have a health care provider ( $\mathrm{HCP})$ & $84.8 \%(56 / 66)$ & $81.5 \%(22 / 27)$ & n.s. \\
\hline $\begin{array}{l}\text { \# times seen HCP in last } 3 \text { years } \\
\text { (ANOVA) }\end{array}$ & $M=10.76$ & $\mathrm{M}=7.10$ & n.s. \\
\hline $\begin{array}{l}\text { Gender of Doctor } \\
\text { Male } \\
\text { Female }\end{array}$ & $\begin{array}{c}94.6 \%(53 / 56) \\
5.4 \%(3 / 56)\end{array}$ & $\begin{array}{l}54.5 \%(12 / 22) \\
45.5 \%(10 / 22)\end{array}$ & .00 \\
\hline HCP very gay-friendly & $60.8 \%(31 / 51)$ & $33.3 \%(5 / 15)$ & .06 \\
\hline $\begin{array}{l}\text { Think HCP is } \\
\text { Gay/Lesbian/Bisexual } \\
\text { Yes } \\
\text { No } \\
\text { Unsure }\end{array}$ & $\begin{array}{l}42.9 \%(24 / 56) \\
35.7 \%(20 / 56) \\
21.4 \%(12 / 56)\end{array}$ & $\begin{array}{l}13.6 \%(3 / 22) \\
54.5 \%(12 / 22) \\
31.8 \%(7 / 22)\end{array}$ & .05 \\
\hline Have insurance & $81.8 \%(54 / 66)$ & $81.5 \%(22 / 27)$ & n.s. \\
\hline $\begin{array}{l}\text { Insurance Type } \\
\text { FFS } \\
\text { HMO } \\
\text { Medicaid } \\
\text { Other } \\
\end{array}$ & $\begin{array}{l}17.3 \%(9 / 52) \\
42.3 \%(22 / 52) \\
15.4 \%(8 / 52) \\
25.0 \%(13 / 52) \\
\end{array}$ & $\begin{array}{r}27.3 \%(6 / 22) \\
36.4 \%(8 / 22) \\
9.1 \%(2 / 22) \\
27.3 \%(6 / 22) \\
\end{array}$ & n.s. \\
\hline Insurance gives choice of LGB HCP & $57.4 \%(27 / 47)$ & $31.8 \%(7 / 22)$ & .04 \\
\hline Told HCP sex orientation & $78.9 \%(45 / 57)$ & $54.5 \%(12 / 22)$ & .03 \\
\hline Sexually active & $75.9 \%(44 / 58)$ & $73.9 \%(17 / 23)$ & n.s. \\
\hline $\begin{array}{l}\text { Ever discuss personal mental health } \\
\text { issues }\end{array}$ & $54.4 \%(31 / 57)$ & $52.4 \%(11 / 21)$ & n.s. \\
\hline Ever discuss drug/alcohol & $41.5 \%(22 / 53)$ & $21.1 \%(4 / 19)$ & n.s. \\
\hline Ever discuss sex/HIV & $55.2 \%(32 / 58)$ & $38.1 \%(8 / 21)$ & n.s. \\
\hline Very comfortable discussing sex & $50.9 \%(28 / 55)$ & $25.0 \%(5 / 20)$ & .04 \\
\hline Taking medications currently & $53.4 \%(31 / 58)$ & $45.5 \%(10 / 22)$ & n.s. \\
\hline Ever missed doses & $77.4 \%(24 / 31)$ & $80.0 \%(8 / 10)$ & n.s. \\
\hline Ever told HCP when doses missed & $73.9 \%(17 / 23)$ & $66.7 \%(6 / 9)$ & n.s. \\
\hline Ever have unprotected sex & $43.9 \%(25 / 57)$ & $60.0 \%(12 / 20)$ & n.s. \\
\hline Ever tell HCP when sex unprotected & $15.6 \%(9 / 47)$ & $13.3 \%(2 / 15)$ & n.s. \\
\hline Ever have an STD & $16.7 \%(11 / 66)$ & $3.7 \%(1 / 27)$ & .09 \\
\hline Had HIV test & $86.2 \%(56 / 65)$ & $61.5 \%(16 / 26)$ & .009 \\
\hline HIV-positive & $24.6 \%(14 / 57)$ & $0.0 \%(0 / 16)$ & .02 \\
\hline Tell HCP HIV status & $82.7 \%(43 / 52)$ & $56.2 \%(9 / 16)$ & .02 \\
\hline
\end{tabular}


TABLE 2. Relationships Between Disclosure of Sexual Orientation to Health Care Provider and Other Variables

\begin{tabular}{|c|c|c|c|}
\hline & $\begin{array}{l}\text { Disclosed Sexual } \\
\text { Orientation to HCP }\end{array}$ & $\begin{array}{l}\text { Not Disclosed Sexual } \\
\text { Orientation to HCP }\end{array}$ & P-Value \\
\hline Age (ANOVA) & $M=41.59(N=57)$ & $M=37.77(N=22)$ & n.s. \\
\hline $\begin{array}{l}\text { Gender } \\
\text { Male } \\
\text { Female }\end{array}$ & $\begin{array}{l}78.9 \%(45 / 57) \\
21.1 \%(12 / 57) \\
\end{array}$ & $\begin{array}{l}54.5 \%(12 / 22) \\
45.5 \%(10 / 22) \\
\end{array}$ & .04 \\
\hline $\begin{array}{l}\text { Sexual Orientation } \\
\text { Gay/Lesbian } \\
\text { Bisexual } \\
\end{array}$ & $\begin{array}{l}89.7 \%(52 / 58) \\
10.3 \%(6 / 58) \\
\end{array}$ & $\begin{array}{l}72.7 \%(16 / 22) \\
27.3 \%(6 / 22) \\
\end{array}$ & .08 \\
\hline $\begin{array}{l}\text { Race } \\
\text { White } \\
\text { Black } \\
\text { Latino } \\
\end{array}$ & $\begin{array}{c}78.8 \%(41 / 52) \\
3.8 \%(2 / 52) \\
17.3 \%(9 / 52)\end{array}$ & $\begin{array}{l}57.9 \%(11 / 19) \\
31.6 \%(6 / 19) \\
10.5 \%(2 / 19)\end{array}$ & .005 \\
\hline $\begin{array}{l}\text { \# times seen HCP in last } 3 \\
\text { years (ANOVA) }\end{array}$ & $10.62(\mathrm{~N}=53)$ & $7.31(\mathrm{~N}=19)$ & n.s. \\
\hline $\begin{array}{l}\text { Gender of Doctor } \\
\text { Male } \\
\text { Female }\end{array}$ & $\begin{array}{r}91.2 \%(52 / 57) \\
8.8 \%(5 / 57) \\
\end{array}$ & $\begin{array}{l}61.9 \%(13 / 21) \\
38.1 \%(8 / 21) \\
\end{array}$ & .004 \\
\hline HCP very gay-friendly & $66.0 \%(33 / 50)$ & $18.8 \%(3 / 16)$ & .001 \\
\hline $\begin{array}{l}\text { Think HCP is } \\
\text { Gay/Lesbian/Bisexual } \\
\text { Yes } \\
\text { No } \\
\text { Unsure }\end{array}$ & $\begin{array}{l}45.6 \%(26 / 57) \\
29.8 \%(17 / 57) \\
24.6 \%(14 / 57)\end{array}$ & $\begin{array}{c}4.8 \%(1 / 21) \\
71.4 \%(15 / 21) \\
23.8 \%(5 / 21)\end{array}$ & .001 \\
\hline Have insurance & $91.4 \%(53 / 58)$ & $95.2 \%(20 / 21)$ & n.s. \\
\hline $\begin{array}{l}\text { Insurance Type } \\
\text { FFS } \\
\text { HMO } \\
\text { Medicaid } \\
\text { Other }\end{array}$ & $\begin{array}{l}11.8 \%(6 / 51) \\
41.2 \%(21 / 51) \\
19.6 \%(10 / 51) \\
27.5 \%(14 / 51) \\
\end{array}$ & $\begin{array}{l}40.0 \%(8 / 20) \\
45.0 \%(9 / 20) \\
0.00 \%(0 / 20) \\
15.0 \%(3 / 20)\end{array}$ & .01 \\
\hline $\begin{array}{l}\text { Insurance gives choice of } \\
\text { LGB HCP }\end{array}$ & $56.8 \%(25 / 44)$ & $35.0 \%(7 / 20)$ & n.s. \\
\hline Sexually active & $79.3 \%(46 / 58)$ & $63.6 \%(14 / 22)$ & n.s. \\
\hline $\begin{array}{l}\text { Ever discuss personal mental } \\
\text { health issues }\end{array}$ & $58.9 \%(33 / 56)$ & $45.5 \%(10 / 22)$ & n.s. \\
\hline Ever discuss drug/alcohol & $50.0 \%(26 / 52)$ & $5.0 \%(1 / 19)$ & .000 \\
\hline Ever discuss sex/HIV & $66.7 \%(38 / 57)$ & $13.6 \%(3 / 22)$ & .000 \\
\hline $\begin{array}{l}\text { Very comfortable } \\
\text { discussing sex }\end{array}$ & $53.6 \%(30 / 56)$ & $15.0 \%(3 / 20)$ & .003 \\
\hline Taking medications currently & $517 \%(30 / 58)$ & $54.5 \%(12 / 22)$ & n.s. \\
\hline Ever missed doses & $76.7 \%(23 / 30)$ & $83.3 \%(10 / 12)$ & n.s. \\
\hline $\begin{array}{l}\text { Ever told HCP when doses } \\
\text { missed }\end{array}$ & $78.3 \%(18 / 23)$ & $60.0 \%(6 / 10)$ & n.s. \\
\hline Ever have unprotected sex & $56.4 \%(31 / 55)$ & $31.8 \%(7 / 22)$ & n.s. \\
\hline $\begin{array}{l}\text { Ever tell HCP when sex un- } \\
\text { protected }\end{array}$ & $23.9 \%(11 / 46)$ & $0.00 \%(0 / 16)$ & .05 \\
\hline Ever have an STD & $15.8 \%(9 / 57)$ & $4.5 \%(1 / 22)$ & n.s. \\
\hline Had HIV test & $89.1 \%(49 / 55)$ & $63.6 \%(14 / 22)$ & 01 \\
\hline $\begin{array}{l}\text { HIV Status } \\
\text { Positive } \\
\text { Negative }\end{array}$ & $\begin{array}{l}28.0 \%(14 / 50) \\
72.0 \%(36 / 50)\end{array}$ & $\begin{array}{c}8.3 \%(1 / 12) \\
917 \%(11 / 12)\end{array}$ & n.s. \\
\hline Tell HCP HIV status & $93.8 \%(45 / 48)$ & $38.5 \%(5 / 13)$ & .000 \\
\hline
\end{tabular}


TABLE 3. Relationships Between Having a Choice of Finding a Gay, Lesbian, or Bisexual Doctor, and Other Variables

\begin{tabular}{|c|c|c|c|}
\hline & LGB Choice & No LGB Choice & $\begin{array}{c}\text { P- } \\
\text { Value }\end{array}$ \\
\hline Age (ANOVA) & $M=43.61(N=34)$ & $M=35.94(N=34)$ & .01 \\
\hline $\begin{array}{l}\text { Gender } \\
\text { Male } \\
\text { Female }\end{array}$ & $\begin{array}{l}79.4 \%(27 / 34) \\
20.6 \%(7 / 34) \\
\end{array}$ & $\begin{array}{l}57.1 \%(20 / 35) \\
42.9 \%(15 / 35)\end{array}$ & .04 \\
\hline $\begin{array}{l}\text { Sexual Orientation } \\
\text { Gay/Lesbian } \\
\text { Bisexual }\end{array}$ & $\begin{array}{l}85.3 \%(29 / 34) \\
14.7 \%(5 / 34) \\
\end{array}$ & $\begin{array}{l}83.3 \%(30 / 36) \\
13.9 \%(5 / 36)\end{array}$ & n.s. \\
\hline $\begin{array}{l}\text { Race } \\
\text { White } \\
\text { Black } \\
\text { Latino }\end{array}$ & $\begin{array}{c}75.0 \%(27 / 32) \\
9.4 \%(3 / 32) \\
15.6 \%(5 / 32) \\
\end{array}$ & $\begin{array}{l}58.6 \%(17 / 29) \\
17.2 \%(5 / 29) \\
24.1 \%(7 / 29) \\
\end{array}$ & n.s. \\
\hline Have a health care provider ( $\mathrm{HCP}$ ) & $91.2 \%(31 / 34)$ & $86.1 \%(31 / 36)$ & n.s. \\
\hline $\begin{array}{l}\text { \# times seen } \mathrm{HCP} \text { in last } 3 \\
\text { years (ANOVA) }\end{array}$ & $M=9.57(N=28)$ & $M=10.03(N=29)$ & n.s. \\
\hline $\begin{array}{l}\text { Gender of Doctor } \\
\text { Male } \\
\text { Female }\end{array}$ & $\begin{array}{c}90.6 \%(29 / 32) \\
9.4 \%(3 / 32) \\
\end{array}$ & $\begin{array}{l}74.2 \%(23 / 31) \\
25.8 \%(8 / 31)\end{array}$ & .08 \\
\hline $\mathrm{HCP}$ very gay-friendly & $60.7 \%(17 / 28)$ & $40.0 \%(10 / 25)$ & n.s. \\
\hline $\begin{array}{l}\text { Think HCP is } \\
\text { Gay/Lesbian/Bisexual } \\
\text { Yes } \\
\text { No } \\
\text { Unsure }\end{array}$ & $\begin{array}{l}34.4 \%(11 / 32) \\
43.8 \%(14 / 32) \\
21.8 \%(7 / 32) \\
\end{array}$ & $\begin{array}{l}19.4 \%(6 / 31) \\
48.4 \%(15 / 31) \\
32.2 \%(10 / 31)\end{array}$ & n.s. \\
\hline Have insurance & $97.0 \%(32 / 33)$ & $94.4 \%(34 / 36)$ & n.s. \\
\hline $\begin{array}{l}\text { Insurance Type } \\
\text { FFS } \\
\text { HMO } \\
\text { Medicaid } \\
\text { Other } \\
\end{array}$ & $\begin{array}{c}25.8 \%(8 / 31) \\
38.7 \%(12 / 31) \\
6.5 \%(2 / 31) \\
29.0 \%(9 / 31) \\
\end{array}$ & $\begin{array}{l}17.6 \%(6 / 34) \\
44.1 \%(15 / 34) \\
23.5 \%(8 / 34) \\
14.7 \%(5 / 34) \\
\end{array}$ & n.s. \\
\hline Told HCP sex orientation & $78.1 \%(25 / 32)$ & $59.4 \%(19 / 32)$ & n.s. \\
\hline Sexually active & $75.0 \%(24 / 32)$ & $71.9 \%(23 / 32)$ & n.s. \\
\hline $\begin{array}{l}\text { Ever discuss personal mental health } \\
\text { issues }\end{array}$ & $60.0 \%(18 / 30)$ & $56.2 \%(18 / 32)$ & n.s. \\
\hline Ever discuss drug/alcohol & $42.9 \%(12 / 28)$ & $36.7 \%(11 / 30)$ & n.s. \\
\hline Ever discuss sex/HIV & $58.1 \%(18 / 31)$ & $46.9 \%(15 / 32)$ & n.s. \\
\hline Very comfortable discussing sex & $54.8 \%(17 / 31)$ & $22.6 \%(17 / 31)$ & .009 \\
\hline Taking medications currently & $59.4 \%(19 / 32)$ & $46.9 \%(15 / 32)$ & n.s. \\
\hline Ever missed doses & $63.2 \%(12 / 19)$ & $93.3 \%(14 / 15)$ & .03 \\
\hline Ever told HCP when doses missed & $69.2 \%(9 / 13)$ & $71.4 \%(10 / 14)$ & n.s. \\
\hline Ever have unprotected sex & $41.9 \%(13 / 31)$ & $56.3 \%(18 / 32)$ & n.s. \\
\hline Ever tell HCP when sex unprotected & $11.1 \%(3 / 27)$ & $20.8 \%(5 / 24)$ & n.s. \\
\hline Ever have an STD & $14.7 \%(5 / 34)$ & $5.6 \%(2 / 36)$ & n.s. \\
\hline Had HIV test & $84.8 \%(28 / 33)$ & $68.6 \%(24 / 35)$ & n.s. \\
\hline $\begin{array}{l}\text { HIV Status } \\
\text { Positive } \\
\text { Negative } \\
\end{array}$ & $\begin{array}{l}70.0 \%(21 / 30) \\
30.0 \%(9 / 30) \\
\end{array}$ & $\begin{array}{l}86.4 \%(19 / 22) \\
13.6 \%(3 / 22) \\
\end{array}$ & n.s. \\
\hline Tell HCP HIV status & $84.6 \%(22 / 26)$ & $66.7 \%(16 / 24)$ & n.s. \\
\hline
\end{tabular}


have disclosed their sexual orientation less, and didn't think their insurance companies gave them a choice of finding a LGB provider. Yet there was no difference between those who felt they did and did not have such a choice in whether they had insurance, or in type of insurance.

Of note, lesbians may have more difficulty with disclosure because they are women as opposed to men, and may be more likely to see physicians who are of different gender than themselves, when compared to gay men. In addition, there was a trend in the study for the men to be more likely to be white, and hence the women in the sample may be more likely to see physicians who are of different ethnicity than themselves. Both of these possibilities may lead to less trust between physicians and patients that may decrease disclosure of sexual orientation and other sensitive areas.

Disclosure of sexual orientation varied by type of medical insurance, but was more common among gay white males. It may be that some types of health insurance (e.g., medicaid or HMO) as opposed to other types of insurance (e.g., fee-for-service) are associated with greater disclosure behaviors, since patients in the former group may be more likely to be HIV positive, and as a result, disclose sexual orientation in explaining the mode of transmission through which the participant became HIV-infected. Though the sample sizes in the current study are too small to test this hypothesis adequately, this possibility can be further explored in future research. Those who disclosed their sexual orientation were also more likely to disclose other sensitive behaviors as well, suggesting that these participants may have a closer bond with their providers as a result of being "out." Alternatively, these findings may result from these participants being more "open" in general. Further research is clearly needed to understand these relationships more fully.

Of note, $24.4 \%$ of respondents were unsure if their physician was gay/lesbian or bisexual, suggesting that as part of the doctor-patient relationship, such information is not disclosed by physicians to their patients.

There are several potential limitations to the study. The number of subjects is comparatively small, though for an initial exploratory study, reveals several critical issues. The significance levels presented are also not corrected for the possible effects of multiple comparisons. Thus, chance associations may have occurred due to the number of comparisons, particularly when we assessed comparisons of marginal statistical significance. However, classical Bonferroni corrections often tend to be 
overly conservative in exploratory research, such as this. In addition, the findings appear to have face validity. For this exploratory study, we thus present our findings without correction, and allow readers to judge areas of interest to be pursued more rigorously in future studies.

In short, the data indicate that lesbians in particular, even at a gay and lesbian community center, have difficulty disclosing their sexual orientation to their providers, and feeling comfortable discussing sex. Most participants did not feel they had a choice of finding a LGB provider. Those who did were more likely to be older and male, suggesting that it requires a certain degree of self-empowerment to pursue the possibility of finding an LGB friendly provider, or to think that one has the options of finding such a provider. The data thus suggest a need for health insurance plans to provide patients with the opportunity to find gay friendly physicians, as it may facilitate communication about substance abuse, high risk sexual behavior and other health topics. In addition, the data suggest the need for primary health care providers to be aware that they may be treating lesbian patients, and that these patients may face particular health concerns.

\section{REFERENCES}

AMA Council on Scientific Affairs (1996). Health care needs of gay men and lesbians in the United States. Journal of the American Medical Association, 275, 1354-1359.

Bhugra, D. (1990). Doctor's attitudes to male homosexuality: a survey. Sexual and Marital Therapy, 5, 167.

Cabaj R.P. (1992). Substance abuse in the gay and lesbian community. In J.H. Lowinson, P. Ruiz, \& R. Millman (Eds.), Substance Abuse: A Comprehensive Textbook (pp. 852-860). Baltimore, MD: Williams \& Wilkins.

Cass, V. (1979). Homosexual identity formation: a theoretical model. Journal of Homosexuality, 4, 219-235.

Cochran, S.D., \& Mays, V.M. (1987). Disclosure of sexual preference to physicians by black lesbian and bisexual women. Western Journal of Medicine, 149, 616-618.

Coleman, E. (1982). Developmental stages of the coming out process. Journal of Homosexuality, 7, 31-43.

Fitzpatrick, R., Dawson, J., Boulton, M., McLean, J., Hart, G., \& Brookes, M. (1994). Perceptions of general practice among homosexual men. British Journal of General Practice, 44, 80-82.

Fox, R.C. (1989). The Sociology of Medicine: A Participant Observer's View. Englewood Cliffs, NJ: Prentice Hall.

Franke, R., \& Leary, M.R. (1991). Disclosure of sexual orientation by lesbians and gay men: a comparison of private and public processes. Journal of Social and Clinical Psychology, 10, 262-269. 
Gerbert, B., Maguire, B.T., Bleeker, T., Coates, T.J., \& McPhee, S.J. (1991). Primary care physicians and AIDS: attitudinal and structural barriers to care. Journal of the American Medical Association, 266, 2837-2842.

Jay, K., \& Young, A. (1979). The Gay Report: Lesbians and Gay Men Speak Out About Sexual Experiences and Lifestyles. New York: Summit Books.

Klitzman, R. (1997). Being Postivie: The Lives of Men and Women with HIV. Chicago: Ivan R. Dee.

Logsdon, D.N., Lazaro, C.M., \& Meier, R.V. (1989). The feasibility of behavioral risk reduction in primary medical care. American Journal of Preventive Medicine, 5, 49-56.

Parsons, T. (1975). The sick-role and the role of the physician reconsidered. Milbank Memorial Fund Quarterly/Health and Society, 53.

Schauffler, H.H., Rodriguez, R., \& Milstein, A. (1996). Health education and patient satisfaction. Journal of Family Practice, 42, 62-68.

Stevens, P.E., \& Hall, J.M. (1988). Stigma, health beliefs and experiences with health care in lesbian women. Image Journal of Nursing School, 20, 69-73.

Wells, J.W., \& Kline, W.B. (1986). Self-disclosure of homosexual orientation. Journal of Social Psychology, 127, 191-197.

West, C. (1984). Routine Complications: Troubles with Talk Between Doctors and Patients. Bloomington, IN: Indiana University Press. 
Copyright of Journal of Homosexuality is the property of Haworth Press and its content may not be copied or emailed to multiple sites or posted to a listserv without the copyright holder's express written permission. However, users may print, download, or email articles for individual use. 